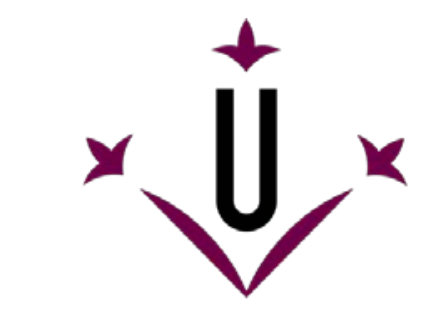

Universitat de Lleida

Document downloaded from:

http://hdl.handle.net/10459.1/60224

The final publication is available at:

https://doi.org/10.1080/13670050.2015.1051508

Copyright

(c) Taylor \& Francis, 2017 


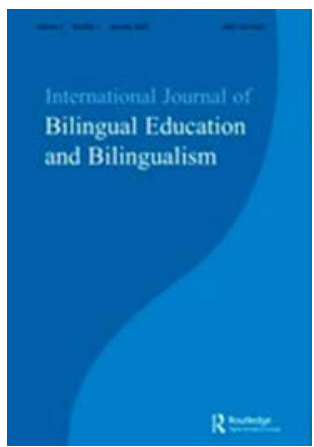

\section{CAN LANGUAGE ATTITUDES BE I MPROVED? A LONGI TUDI NAL STUDY OF I MMI GRANT STUDENTS I N CATALONI A (SPAI N)}

\begin{tabular}{|r|l|}
\hline Journal: & International J ournal of Bilingual Education and Bilingualism \\
\hline Manuscript ID: & BEB-1299.R2 \\
\hline Manuscript Type: & Paper \\
\hline Keywords: & $\begin{array}{l}\text { Language Attitudes, Attitude change, Multilingualism, Immigration, } \\
\text { Catalonia }\end{array}$ \\
\hline & $\begin{array}{l}\text { This study explores changes in attitudes towards Catalan, Spanish, and } \\
\text { English over a two-year period, on the part of secondary education } \\
\text { students of immigrant origin residing in Catalonia. It aims to provide new } \\
\text { data by adopting a longitudinal design and by focusing on the immigrant } \\
\text { population, which has raised new challenges for the Catalan society and } \\
\text { education system. Data was collected from 72 secondary education } \\
\text { students who answered a language attitudes questionnaire twice, at a two- } \\
\text { year interval. The instrument chosen has been successfully used in the } \\
\text { area previously (Huguet, Janés, and Chireac 2008; Madariaga, Huguet, and } \\
\text { Lapresta 2013). Findings showed that attitudes towards Catalan improved, } \\
\text { while attitudes towards Spanish and English remained stable, based on } \\
\text { which we discuss the strength of language attitudes in this particular } \\
\text { context. Furthermore, the socio-demographic and affective variables } \\
\text { traditionally investigated as determinants of language attitudes were not } \\
\text { found to influence the processes of attitude change. }\end{array}$ \\
\hline
\end{tabular}





\title{
CAN LANGUAGE ATTITUDES BE IMPROVED? A LONGITUDINAL STUDY OF IMMIGRANT STUDENTS IN CATALONIA (SPAIN)
}

\author{
This study explores changes in attitudes towards Catalan, Spanish, and English over a \\ two-year period, on the part of secondary education students of immigrant origin \\ residing in Catalonia. It aims to provide new data by adopting a longitudinal design and \\ by focusing on the immigrant population, which has raised new challenges for the \\ Catalan society and education system. Data was collected from 72 secondary education \\ students who answered a language attitudes questionnaire twice, at a two-year interval. \\ The instrument chosen has been successfully used in the area previously (Huguet, \\ Janés, and Chireac 2008; Madariaga, Huguet, and Lapresta 2013). Findings showed \\ that attitudes towards Catalan improved, while attitudes towards Spanish and English \\ remained stable, based on which we discuss the strength of language attitudes in this \\ particular context. Furthermore, the socio-demographic and affective variables \\ traditionally investigated as determinants of language attitudes were not found to \\ influence the processes of attitude change.
}

Keywords: language attitudes, attitude change, immigration, multilingualism, Catalonia (Spain)

\section{Introduction}

Language attitudes have a key role in issues concerning language learning (Baker 1992;

Gardner 1985; Garrett 2010), language use (Moriarty 2010), language variation and maintenance (Fishman 1985; Schüpbach 2009; Zhang and Slaughter-Defoe 2009), identity construction and expression (Boninger, Krosnick, and Berent 1995; Hogg and Smith 2007; Lapresta and Huguet 2008; Wood 2000), and language policies’ design and implementation (Lewis 1981). Accordingly, it is important to study and understand how to influence and change attitudes in order to elicit the desired language behaviours (Glasman and Albarracín 2006; McKenzie 2010).

These topics are of special interest in areas where two or more languages are in contact, such as in the case of Catalonia, one of Spain's bilingual autonomous communities. 
Moreover, language attitudes and attitude change have become increasingly relevant as the influx of immigrants increased and new educational and linguistic measures have been required to help the newcomers learn the languages spoken in Catalonia and integrate in the host society. Therefore, this paper investigates language attitude change in the case of immigrant students living in the multilingual and multicultural context of Catalonia.

\section{Language attitudes and attitude change}

Attitudes, a core concept of social sciences, have been defined from different angles, varying in specificity and complexity. According to the working definition adopted for this study, an attitude is 'a psychological tendency that is expressed by evaluating a particular entity with some degree of favour or disfavour' (Eagly and Chaiken 1993, 1). In terms of this definition, attitudes are directed toward an entity, known as the attitude object, which can be anything discriminated by the individual (Eagly and Chaiken 2007). Thus, language can represent 'an object being seen as favourable or unfavourable’ (Baker 1992, 11). However, the term language attitudes is an umbrella term, which refers to various attitudinal objects, including languages, dialects, speech styles, speakers, communities, language learning, language use, etc.

Accordingly, three main lines of research concerning language attitudes have been developed. Firstly, the speaker evaluation paradigm relies on the matched-guise technique, developed by Lambert et al. (1960). This method requires participants to evaluate speakers of the target language variety. The personality evaluations are then used to infer attitudes (see Giles and Billings [2004] for a recent review and Fuertes et al. [2012] for a meta-analysis). Secondly, language attitudes have been intensively investigated in the context of language learning, within the framework of the Socio-Educational Model of Second Language Acquisition (Gardner 1985) or the L2 Motivational Self System theory (Dörnyei 2009). One 
of the most used instruments has been Gardner’s (1985) Attitude/ Motivation Test Battery (AMTB), which measures attitudes towards language learning, the learning situation, and the language community (see Gardner [2009] for a review and Masgoret and Gardner [2003] for a meta-analysis). Finally, there is a research tradition focused on attitudes towards languages, with roots in the works of Sharp et al. (1973) and Baker (1992). Attitudes towards languages are usually assessed through questionnaires that consist of dichotomous or Likert scale items. The present paper subscribes to this latter line of research.

Furthermore, one of the main points of interest in the field is the dynamic aspect of attitudes, as researchers generally agree that attitudes change (Bohner and Dickel 2011; Crano, Cooper, and Forgas 2010; Petty, Wheeler, and Tormala 2003; Wood 2000). Attitude change means that ‘a person's evaluation is modified from one value to another' (Petty and Wegener 1998, 324). The processes of attitude change involve 'both the retrieval of stored evaluations and the consideration of new evaluative information to varying extents' (Bohner and Dickel 2011, 397). Moreover, change is moderated by attitude strength. Thus, strong attitudes are firmly crystallized and relatively resistant to change (Eagly and Chaiken [1995] 2014).

Baker (1992) argued that language attitude change can be prompted by personal experiences, significant events (e.g., violent episodes, mass protests, and government imposed policies), communities, families, peer groups, institutions, and mass-media. Moreover, Mantle-Bromley (1995) showed that specially designed language learning programs can improve language attitudes. Additionally, Gardner and his associates (2004) found that the classroom environment and students’ academic results also determined changes in language attitudes. Nonetheless, the authors concluded that 'the possibility of change is not great, but it is larger for variables directly associated with the classroom environment than for more general variables' (Gardner et al. 2004, 28). 
There is also evidence that language attitudes tend to decline over time. For instance, Baker (1992) reported a decrease in favourability of attitudes towards Welsh over a two year period on the part of secondary education students in Wales. The attitude change was influenced by language use, perceived linguistic competence, the language medium of the school, and youth culture (e.g., participation in cultural Welsh activities). Similarly, in the context of foreign language learning in the USA, Heining-Boynton and Haitema (2007) found that attitudes towards French and Spanish declined over a four-year period.

Additionally, the repeated cross-sectional study carried out by Dörnyei and Csizér (2002) in Hungary showed a decline of the attitudes towards German, French, Italian, and Russian. English was an exception, as it continued to receive positive evaluations, which the authors interpreted as a result of globalisation. Furthermore, in a longitudinal study conducted in Catalonia, Tragant (2006) found no evidence of a decline in attitudes towards English, regardless of the number of hours of instruction. Henry and Apelgren (2008) also reported that overall the attitudes towards English held by Sweden students remained stable.

\section{The socio-linguistic and educational context of Catalonia}

The investigation took place in Catalonia, one of Spain's bilingual autonomous communities, which has witnessed significant changes in language policies, language uses and attitudes. This process of change and language revitalization started with the ratification of Catalan's coofficial status alongside Spanish in 1979 and the linguistic normalization policy adopted in 1983. One of the critically important measures was the implementation of a bilingual education system, with Catalan as the vehicular language. Its main aim is that children achieve competence in both Catalan and Spanish (Government of Catalonia 2010).

The Catalan linguistic immersion program was initially designed for students from Spanish-speaking families in order to help them learn both languages. The model 
implemented has been early total immersion, as Catalan represents the only medium of instruction from the beginning of schooling, regardless of the students' home language. Thus, the program also guarantees the maintenance of the home language in the case of children from Catalan-speaking families. All these accomplishments of the Catalan educational programs have been generally labelled as immersion education (Huguet 2007).

New challenges for the Catalan education system were created by the influx of immigrants in the first decade of this century. Catalonia was one of the most affected regions of the Spanish state, being the autonomous community with the largest immigrant population. More precisely, it currently hosts 1,085,976 foreigners, the equivalent of $14.5 \%$ of the total population (National Statistics Institute 2014). Among the various and wide-ranging outcomes of this upsurge in immigration and the consequent cultural and demographic diversity created, we emphasize the impact had at educational level, as the Catalan education system had to adapt in order to successfully integrate 166,694 students of immigrant origin (Ministry of Education, Culture, and Sports 2014) and to adequately respond to their particular needs.

The issue of the education of immigrant students was addressed by several policies, among which the most complex was the Plan for Language and Social Cohesion ('Pla per a la Llengua i la Cohesió Social'), approved in 2004. Besides the regulation of the newcomers’ reception classrooms ('aules de acollida'), this plan also intended to involve the community, in order to create a support network outside school (Government of Catalonia 2009). It was complemented by the Plan for the Actualisation of the Immersion Methodology in the Current Sociolinguistic Context 2007-2013 ('Pla per a l’Actualització de la Metodologia d’Immersió en l'Actual Context Sociolingüistic 2007-2013’), which aims that, by the end of the compulsory education, all students, regardless of their first language, become competent 
in both Catalan and Spanish and can understand and deliver oral and written messages in at least one foreign language.

In order to successfully implement these educational and linguistic policies and to help immigrant students learn the two official languages of the territory, their language attitudes have to be considered (Lewis 1981; Huguet 2006; Lapresta, Chireac, Huguet, Janés, Navarro, Querol, and Sansó 2009; Strubell 2001). Immigrant students have been found to show more favourable attitudes towards Spanish and English than towards Catalan (Bernaus, Masgoret et al. 2004; Bernaus et al. 2007; Huguet, Janés, and Chireac 2008; Madariaga, Huguet, and Lapresta 2013).

Furthermore, according to Huguet, Janés, and Chireac (2008), immigrant students’ attitudes towards Spanish were more favourable if the students' home language was Spanish, they were from Latin America, or if their parents had a high socio-professional status. Positive attitudes towards Catalan were more present in the case of students with a length of residence of more than six years, who were born in the host society or immigrated before the age of ten, or who started schooling in Catalonia. These findings were confirmed by Madariaga, Huguet, and Lapresta (2013), who investigated 1206 autochthonous and immigrant secondary education students and also found that their attitudes were influenced by area of origin, home language, length of residence, age of arrival, and place of birth. Meanwhile, Lapresta et al. (2009) analysed 35 semi-structured interviews of immigrant students and revealed the importance of self-identification and personal perception of school and social integration in fostering positive attitudes towards Catalan and Spanish.

As we have seen, the processes of language attitude formation are influenced by various socio-demographic and affective variables. However, little is known regarding the process of language attitude change and the variables involved. Therefore, the present study aims to bring new and unique data about language attitude change by concentrating on a 
group not studied previously under a longitudinal design - immigrant students in Catalonia. The focus of the investigation was placed on secondary education students not only because the attitudes of young people are especially relevant since they 'will likely determine the future of the language' (Chambers 1995, 147), but also because of the changes in attitudes recorded at this age (Baker 1992).

Consequently, we set out to determine the existence and extent of change in the attitudes towards the official languages of the region, Catalan and Spanish, and towards English, the most studied foreign language in the territory and the current international 'lingua franca'. We expected to find changes in attitudes over a two-year interval. Furthermore, we hypothesised that the variables influencing language attitudes would also impact their change.

\section{Method}

\section{Participants}

The participants were 72 secondary education students of immigrant origin (32 boys and 40 girls), with ages between 13 and 15 years old $(M=13.67, S D=0.69)$. The majority of students (83.3\%) were born outside Catalonia. Overall, they came from Latin America (38.9\%), Africa (27.8\%), Europe (25\%), and Asia and Oceania (6\%). The students were enrolled at five schools across Catalonia, located in Barcelona, Girona, Guissona, Reus, and Torroella de Montgri.

\section{Materials}

The attitude questionnaire selected has been successfully used in Catalonia (Navarro and Huguet 2005; Huguet, Janés, and Chireac 2008; Madariaga, Huguet, and Lapresta 2013). The instrument follows the model of the one constructed by Sharp et al. (1973) and it was adapted 
to the Catalan context by the Catalan Education Service ('Servei d'Ensenyament del Català' - SEDEC) and then readapted to the current characteristics of the secondary education student population, taking into account the immigrant group. For each language investigated, a scale containing ten items was used. The items were designed to capture the general attitudes towards a particular language and encompassed various aspects, such as the intrinsic aesthetic characteristics of the language (e.g., 'Catalan is an ill-sounding language', 'Spanish is a beautiful language'), the importance of the language (e.g., 'Catalan is more important than Spanish'), language learning (e.g., 'Learning Catalan is unpleasant', 'I approve of all the children in my town studying Catalan'), and language use (e.g., 'We should all try harder to use Catalan more frequently', 'I like (or would like) to speak Catalan'). The items were dichotomous, meaning that students were asked to indicate if they agreed or disagreed with each statement. They were designed so that five of the statements would indicate a positive attitude towards a particular language and the other five a negative attitude. The answers were codified with +1 when they were favourable and -1 when they were unfavourable towards the respective language. These values were summed to obtain the final score that could oscillate between -10 and +10 . The three scales used, along with their Cronbach's alpha coefficients appear in the Appendix.

Furthermore, a socio-linguistic survey was administered to collect data regarding a series of socio-demographic and affective variables. The variables of interest were: gender, age, place of birth, area of origin, length of residence, socio-cultural status, and socioprofessional status. Furthermore, a series of four-point Likert scale items measured participants' self-identification with Catalonia, Spain, and the area of origin. The use of Catalan, Spanish, and that of the first language (L1) were estimated as a function of the rankings allocated to their use in seven contexts: peers in the school yard, peers outside school, adults outside school, teachers, reading, watching TV, and writing. 


\section{Procedure}

The participants filled in a questionnaire assessing their language attitudes and a sociolinguistic survey twice - when they were in the second and fourth grade, respectively. The instruments were administered collectively in Catalan, the language of instruction in the Catalan education system. The participation was voluntary and the students were guaranteed confidentiality.

\section{Statistical treatment}

To investigate the effect of the independent variables on attitude change towards Catalan, Spanish, and English we conducted various analyses, including descriptive statistics, pairedsample t tests, mixed-design ANOVAs, and simple linear regressions. For this purpose, the software package SPSS v.20 was used. This variety of techniques reflects the mixed type of data. Thus, we have worked with both categorical and continuous variables, because we chose to explore the variables in their original form, in order to avoid loss of data and power (Field 2013; Tabachnick and Fidell 2007).

\section{Results}

\section{Attitude change}

To test if there were any significant changes in attitudes towards Catalan, Spanish and English over the two-year interval, a series of paired-samples t tests were conducted. The results indicated an improvement in the attitudes towards Catalan $\left(t_{(71)}=-2.37, p=.021 d=\right.$ 0.28). More precisely, the attitudes expressed in the fourth grade $(M=6.38, S D=3.28)$ were more favourable than in the second grade $(M=5.31, S D=4.24)$. The attitudes towards Spanish tended to remain positive $\left(t_{(71)}=-0.27, p=.789, d=0.04\right)$ between the second $(M=$ $6.76, S D=2.85)$ and fourth grade $(M=6.89, S D=3.45)$. Furthermore, attitudes towards 
English also seemed to be stable $\left(t_{(71)}=-0.27, p=.790, d=0.04\right)$, as no significant differences were found between the second $(M=6.29, S D=3.96)$ and the fourth grade $(M=6.42, S D=$ 4.24) (see figure 1). Also, it can be seen that, overall, attitudes towards all three languages were favourable.

[INSERT FIGURE 1 AROUND HERE]

\section{Determinants of attitude change}

Individual attitude change was operationalized as the raw difference between the attitudes expressed in fourth and second grade. We considered difference scores to be the most adequate for our purposes because they represent a useful, intuitive, and straightforward measure of change at individual level when only two waves of data are available (de Vaus 2001; Rogosa 1995; Williams and Zimmerman 1996).

The means of the difference scores confirmed the aforementioned results of the paired-samples t tests. More precisely, in the case of Catalan, the mean of attitude change scores was $1.07(S D=3.83)$, indicating a slight improvement. Meanwhile, the means of the difference scores for Spanish $(M=0.13, S D=3.95)$ and English $(M=0.13, S D=3.97)$ showed that the group's attitudes towards these two languages remained at the same level.

Furthermore, the effects of socio-demographic variables on attitude change for Catalan, Spanish, and English were investigated by mixed-design ANOVAs. Each of the variables of interest was introduced as the between-subjects factor and language attitude change (attitude change towards Catalan, attitude change towards Spanish, attitude change towards English) as the within-subjects factor. This technique allowed exploring if the variables analysed influence language attitude change and if the effects vary among the three languages. Table 1 presents the corresponding descriptive statistics.

[INSERT TABLE 1 AROUND HERE] 
The results of the 2x3 mixed design ANOVA with gender (male, female) as the between-subjects factor showed that language attitude change did not vary by gender, since neither the interaction effect $\left(F_{(2,140)}=0.09, p=.912\right)$ nor the main effect $\left(F_{(1,70)}=1.50, p=\right.$ .225) were significant. Similarly, place of birth (Catalonia, abroad) was introduced as the between-subjects factor. The interaction between place of birth and language attitude change $\left(F_{(2,140)}=2.39, p=.095\right)$ and the main effect of place of birth $\left(F_{(1,70)}=0.04, p=.836\right)$ were also not statistically significant.

However, the 4x3 mixed design ANOVA that considered the between-subjects variable area of origin (Europe, Africa, Latin America, Asia and Oceania) indicated that the attitudes of the three languages changed in different directions and at different degrees depending on the area of origin $\left(F_{(6,136)}=2.249, p=.042\right)$. Further, to examine the patterns of attitude change we tested the simple effects of each variable. According to the results of Bonferroni adjusted tests, significant differences were found only for the group from Africa, whose attitude change towards Catalan differed from Spanish and English. More specifically, the change of attitudes towards Catalan registered for students coming from Africa was greater than the attitude change towards Spanish $\left(t_{(71)}=2.85, p=.017, d=0.49\right)$, and English $\left(t_{(71)}=3.12, p=.008, d=0.56\right)$.

Socio-professional status (high, medium, low) was also introduced as the betweensubjects factor in a 3x3 mixed design ANOVA. No significant interaction $\left(F_{(4,138)}=1.95, p=\right.$ $.106)$ or main effects $\left(F_{(2,69)}=0.19, p=.822\right)$ were revealed. Similarly, the interaction between socio-cultural status (university, secondary, elementary education) and language attitude change was also not significant $\left(F_{(4,138)}=1.21, p=.311\right)$. Besides, no main effect of socio-cultural status was found $\left(F_{(2,138)}=0.64, p=.527\right)$.

[INSERT TABLE 2 AROUND HERE] 
Furthermore, simple regression analyses were conducted to investigate the effects of length of residence, use of Catalan, use of Spanish, use of L1, self-identification with Catalonia, self-identification with Spain, and self-identification with area of origin on language attitude change. Each variable was tested as a predictor of attitude change towards Catalan, Spanish, and English, respectively. The summary of the corresponding 21 simple regression analyses is presented in table 2. As it can be seen, contrary to our expectations, none of the variables analysed were found to be significantly related to attitude change. Additionally, these variables explained less than $1 \%$ of the variance of the attitude change variables.

\section{Discussion}

Our longitudinal study aimed to investigate how the attitudes towards Catalan, Spanish, and English held by students of immigrant origin change over two years. Overall, only attitudes towards Catalan changed, becoming more positive. Attitudes towards Spanish and English seemed to be more stable, as no significant changes were found at group level.

These findings mostly differ from previous research, which has shown that language attitudes tend to decline over time (Baker 1992; Bernaus et al. 2007; Dörnyei and Csizér 2002; Heining-Boynton and Haitema 2007). A possible explanation of why we found no evidence of attitude change towards Spanish and English and rather small changes in attitudes towards Catalan can be proposed in terms of attitude strength, taking into consideration the social and linguistic context investigated. Thus, the substantial links among attitudes, languages, and identity (Hogg and Smith 2007; Zhang and Slaughter-Defoe 2009) suggest that language attitudes could be considered strong attitudes. Furthermore, while much of the aforementioned research on language attitude change focused on attitudes towards various foreign languages, the present investigation examined attitudes towards official 
languages in a context of bilingual education. Specifically, Catalan and Spanish are vehicular languages in Catalonia, strongly linked with group membership and identity (Lapresta and Huguet 2008; Lapresta et al. 2009). This implies that the language attitudes we studied could be stronger than the attitudes towards languages with which the respondents have limited contact, as in the case of foreign languages.

Accordingly, Spanish is one of the official and majority languages in Catalonia. Besides being related to popular culture, Spanish is also the third most spoken language worldwide, carrying thus a substantial instrumental value. Additionally, some of the students have Spanish as first language or had early contacts with the language, prior to their arrival in Catalonia. It is possible that their attitudes had been formed and strengthened by their previous experiences, which contributed to their relative stability.

Regarding Catalan, the results obtained bring new data on the topic. The attitudes towards Catalan became more positive over the two-year interval. Their improvement suggests several possibilities. Firstly, it is possible that immigrant students' attitudes towards Catalan were not firmly crystallised. Thus, probably at first Catalan is seen as an unpleasant and troublesome surprise, as usually students do not expect to encounter another official language besides Spanish. However, in time, as they understand and become more familiarised with the linguistic landscape of Catalonia they start to appreciate its language. In this regard, Catalan is the language of education, culture, and politics, and knowledge of Catalan increases opportunities to access jobs. Knowing and using the regional language confers certain advantages and represents a catalyst of social and professional advancement. These instrumental advantages could become more salient for students as they grow up and start to focus more on their professional lives. The attitudes of immigrant students could also reflect the role of Catalan in fostering social integration, as children perceive the positive reactions elicited by their use of the local language. As a result, positive attitudes and 
increased use of Catalan enhance interactions with the autochthonous population.

Accordingly, their will to integrate in the host society could translate into positive attitudes towards Catalan.

Secondly, the increase in attitudes' favourability could be a consequence of the linguistic policies and measures implemented within the framework of the 'Plan for the Actualisation of the Immersion Methodology in the Current Sociolinguistic Context 20072013', aiming to promote more positive attitudes towards Catalan. Although these signs are encouraging, we have to consider that the improvement in attitudes towards Catalan was rather weak. This indicates that although the efforts are headed in the right direction, more is needed in order to achieve the desired outcomes. Nonetheless, this positive change represents good news for the maintenance of the Catalan language, which depends on recruiting new speakers among the immigrant groups (Strubell 2001).

Our findings regarding English showing that students have maintained favourable attitudes coincide with results obtained in Catalonia (Tragant 2006), Hungary (Dörnyei and Csizér 2002), and Sweden (Henry and Apelgren 2008). English seems to represent an exception from the general trend of attitude decline so common among foreign languages. In all likelihood, due to its status as international 'lingua franca', English has a set of attitudinal and motivational particularities that distinguishes it from the other foreign languages, regardless of the social and linguistic context. Continually gaining more ground and with a constantly increasing number of speakers, English has a strong instrumental value, which is probably perceived and reflected in students' attitudes. In this sense, Bernaus, Masgoret et al. (2004) showed that immigrant students learning English had predominantly instrumental orientations. Tragant (2006) also brought evidence that secondary education students were more instrumentally oriented than younger learners. Furthermore, mass-media and popular culture also promote positive attitudes towards English (Baker 1992). Dörnyei and Csizér 
(2002) underlined that English has become associated with a global culture. As a result, we can no longer speak of integration into an L2 community in the traditional manner, as it is no longer clear who the L2 speakers and L2 communities are. Hence, a broader frame of reference is needed to understand the integrative value of learning English.

In addition, the socio-demographic factors traditionally found to influence language attitudes (i.e., gender, place of birth, area of origin, socio-professional status, socio-cultural status, length of residence), and the language use and self-identification variables that we examined were not related to individual attitude change. Nonetheless, we have to take into account that the lack of significance might be in part due to the reduced amount of change or lack thereof observed in the context of our research. Thus, the low percentage of variance explained by the variables analyzed is probably a result of the little variance of the criterion variables in the sample.

These findings suggest that the language attitudes analyzed in the Catalan context might be strong attitudes, and, thus, more resistant to change. However, as Eagly and Chaiken ([1995] 2014) underlined, even strong attitudes can be changed with the adequate techniques. Consequently, stronger and more extensive efforts are needed to foster the development of positive attitudes and to encourage attitude change on the part of immigrant students. To be successful, actions must be taken not only at educational level, but outside schools too. In this sense, encouragement of intercultural contact between communities promotes integration and social cohesiveness (Baker 1992). The first steps in this direction seem to have been made with the Community Plan ('Pla educatiu d'entorn’), designed to involve the community in the creation of a support network outside school. Measures promoting voluntary language related behaviours and positive reception and appreciation of newcomers on the part of local residents could also encourage immigrants' social integration and positive attitudes towards the host society and its languages. 
Nonetheless, the results of this paper should be interpreted cautiously in view of the small sample size, which reduced statistical power and limited the generalization possibilities. Moreover, the study conducted was of quantitative nature and, consequently, it suffers from the limits associated with this approach, such as structural bias and lack of more in-depth information, usually provided by qualitative research.

Accordingly, future studies could also consider qualitative aspects in order to obtain a more comprehensive understanding of the processes of language attitude change. Further studies are also required to identify which factors determine language attitude change and the most effective techniques to improve language attitudes in specific social and linguistic contexts. Moreover, after seeing that the effects of the investigated factors were not statistically significant, similar investigations conducted in different contexts would be helpful to establish if these variables have any influence on attitude change. Likewise, future research is needed to confirm and investigate the strength of language attitudes, as well as its determinants.

\section{Conclusions}

The present study has analysed change in the attitudes towards Catalan, Spanish, and English of immigrant secondary education students. The findings showed that the variables traditionally considered determinants of language attitudes played little or no part in the processes of attitude change, which highlights the necessity of looking for other possible factors that could promote attitude improvement. Furthermore, due to the strong links between language attitudes and identity, on the one hand, and the role and status of the languages investigated in the Catalan context, on the other hand, we suggest that the attitudes towards Catalan, Spanish, and English could be considered strong attitudes. Thus, it might be more difficult to change these attitudes. However, change seems to be possible, as indicated 
by the improvement of the attitudes towards Catalan. Hence, we hope to see these findings become part of a larger body of research focused on language attitude change, with the aim of fostering language learning and social integration.

This work was supported by the Ministry of Economy and Competitiveness of the Government of Spain [grant number EDU2014-54093-R] and Government of Catalonia - Agència de Gestió d’ajuts Universitaris i de Recerca (AGAUR) [grant number 2014 SGR 208].

\section{References}

Baker, C. 1992. Attitudes and language. Clevedon: Multilingual Matters.

Bernaus, M, A.- M. Masgoret, R. C. Gardner, and E. Reyes. 2004. 'Motivation and Attitudes towards Learning Languages in Multicultural Classrooms.' International Journal of Multilingualism 1 (2): 75-89. doi:10.1080/14790710408668180.

Bernaus, M., E. Moore, and A. Cordeiro Azevedo. 2007. 'Affective Factors Influencing Plurilingual Students' Acquisition of Catalan in a Catalan-Spanish Bilingual Context.' The Modern Language Journal 91 (2): 235-246. doi:10.1111/j.15404781.2007.00542.x.

Bohner, G., and N. Dickel. 2011. 'Attitudes and Attitude Change.' Annual Review of Psychology 62: 391-417. doi:10.1146/annurev.psych.121208.131609.

Boninger, D. S., J. A. Krosnick, and M. K. Berent. 1995. ‘Origins of Attitude Importance: Self-Interest, Social Identification, and Value Relevance.’ Journal of personality and social psychology 68 (1): 61-80.

Chambers, J. K. 1995. Sociolinguistic theory. Oxford: Blackwell.

Crano, W. D., J. Cooper, and J. P. Forgas. 2010. ‘Attitudes and Attitude Change. An Introductory Review.' In The Psychology of Attitudes and Attitude Change, edited by Joseph P. Forgas, Joel Cooper, and William D. Crano, 3-18. New York: Psychology Press.

de Vaus, D. 2001. Research design in social research. London: Sage.

Dörnyei, Z. 2009. 'The L2 motivational self-system'. In Motivation, language identity and the L2 self, edited by Zoltan Dörnyei and Ema Ushioda, 9-42. Clevedon: Multilingual Matters.

Dörnyei, Z., and K. Csizér. 2002. 'Some Dynamics of Language Attitudes and Motivation: 
Results of a Longitudinal Nationwide Survey.' Applied Linguistics 23 (4): 421-62. doi:10.1093/applin/23.4.421.

Eagly, A. H., and S. Chaiken. 1993. The Psychology of Attitudes. New York: Harcourt Brace Jovanovich College Publishers. 
Eagly, A. H., and S. Chaiken. (1995) 2014. ‘Attitude Strength, Attitude Structure, and Resistance to Change.' In Attitude Strength: Antecedents and Consequences, edited by Richard E. Petty and Jon A. Krosnick, 413-432. Reprint, Mahwah, NJ: Lawrence Erlbaum.

Eagly, A. H., and S. Chaiken. 2007. 'The Advantages of an Inclusive Definition of Attitude.' Social Cognition 25 (5): 582-602. doi:10.1521/soco.2007.25.5.582.

Field, A. 2013. Discovering Statistics Using IBM SPSS Statistics. 4th ed. London: Sage.

Fishman, J. A. 1985. The Rise and Fall of the Ethnic Revival: Perspectives on Language and Ethnicity. Berlin: Walter de Gruyter.

Fuertes, J. N., W. H. Gottdiener, H. Martin, T. C. Gilbert, and H. Giles. 2012. ‘A MetaAnalysis of the Effects of Speakers' Accents on Interpersonal Evaluations.' European Journal of Social Psychology 42 (1): 120-33. doi:10.1002/ejsp.862.

Gardner, R. C. 1985. Social Psychology and Second Language Learning: The Role of Attitudes and Motivation. London: Edward Arnold.

Gardner, R. C. 2009. 'Gardner and Lambert (1959): Fifty years and counting.’ Paper presented at the Canadian Association of Applied Linguistics Symposium, Ottawa. May 27-29. http://publish.uwo.ca/ gardner.

Gardner, R. C., A.-M. Masgoret, J. Tennant, and L. Mihic. 2004. 'Integrative Motivation: Changes during a Year-Long Intermediate-Level Language Course.’ Language Learning 54 (1): 1-34. doi:10.1111/j.1467-9922.2004.00247.x.

Garrett, P. 2010. Attitudes to Language. Cambridge: Cambridge University Press.

Giles, H., and A.C. Billings. 2004. 'Assessing Language Attitudes: Speaker Evaluation Studies.' In The Handbook of Applied Linguistics, edited by A. Davies and C. Elder, 187-205. Oxford: Blackwell Publishing.

Government of Catalonia. 2007. Pla per a l'Actualització de la Metodologia d'Immersió en l'Actual Context Sociolingüistic 2007-2013. http://www.xtec.cat/alfresco/d/d/workspace/SpacesStore/91738e79-a419-45fd-b4eb358af62486f6/pil.pdf.

Government of Catalonia. 2009. Pla per a la llengua i la cohesió social. Educació i convivència intercultural. http://www.xtec.cat/lic/intro/documenta/annex1_aules_nov_09.pdf.

Government of Catalonia. 2010. Language policy report 2010. www20.gencat.cat/docs/Llengcat/Documents/InformePL/Arxius/IPL2010_EN.pdf. 
Glasman, L. R, and D. Albarracín. 2006. 'Forming Attitudes That Predict Future Behavior: A Meta-Analysis of the Attitude-Behavior Relation.’ Psychological Bulletin 132 (5): 778822. doi:10.1037/0033-2909.132.5.778.

Heining-Boynton, A. L., and T. Haitema. 2007. 'A Ten-Year Chronicle of Student Attitudes toward Foreign Language in the Elementary School.’ The Modern Language Journal 91 (2): 149-68. doi:10.1111/j.1540-4781.2007.00538.x.

Henry, A., and B. M. Apelgren. 2008. 'Young Learners and Multilingualism: A Study of Learner Attitudes before and after the Introduction of a Second Foreign Language to the Curriculum.' System 36 (4): 607-623. doi:10.1016/j.system.2008.03.004.

Hogg, M. A., and J. R. Smith. 2007. 'Attitudes in Social Context: A Social Identity Perspective.’ European Review of Social Psychology 18 (1): 89-131. doi:10.1080/10463280701592070.

Huguet, Á. 2006. 'Attitudes and Motivation versus Language Achievement in CrossLinguistic Settings. What Is Cause and What Effect?' Journal of Multilingual and Multicultural Development 27 (5): 413-29. doi:10.2167/jmmd426.1.

Huguet, Á. 2007. 'Minority Languages and Curriculum: The Case of Spain.’ Language, Culture and Curriculum 20 (1): 70-86. doi:10.2167/lcc327.0.

Huguet, Á., J. Janés, and S. M. Chireac. 2008. 'Mother Tongue as a Determining Variable in Language Attitudes. The Case of Immigrant Latin American Students in Spain.' Language and Intercultural Communication 8 (4): 246-260. doi:10.1080/14708470802303082.

Lambert, W. E., R. C. Hodgson, R. C. Gardner, and S. Fillenbaum. 1960. ‘Evaluational Reactions to Spoken Languages.' The Journal of Abnormal and Social Psychology 60 (1): 44-51.

Lapresta, C., and Á. Huguet. 2008. 'A Model of Relationship between Collective Identity and Language in Pluricultural and Plurilingual Settings: Influence on Intercultural Relations.' International Journal of Intercultural Relations 32 (3): 260-281. doi:10.1016/j.ijintrel.2007.10.004.

Lapresta, C., S. M. Chireac, Á. Huguet, J. Janés, J. L. Navarro, M. Querol, and C. Sansó. 2009. Actitudes lingüísticas, escuela e inmigración. Los escolares ante la diversidad lingüística y cultural. Madrid: Ministry of Education. Department of General Information and Publications.

Lewis, E. G. 1981. Bilingualism and bilingual education. Oxford: Pergamon. 
Madariaga, J. M., Á. Huguet, and C. Lapresta. 2013. 'Attitudes, Social Pressure and Inclusive Education in Classrooms with Cultural and Linguistic Diversity.' Educación XXI 16 (1): 305-328. doi:10.5944/educXX1.16.1.728.

Mantle-Bromley, C. 1995. 'Positive Attitudes and Realistic Beliefs: Links to Proficiency.' The Modern Language Journal 79 (3): 372-386. doi:10.1111/j.15404781.1995.tb01114.x.

Masgoret, A.- M., and R. C. Gardner. 2003. 'Attitudes, Motivation, and Second Language Learning: A Meta-Analysis of Studies Conducted by Gardner and Associates.' Language Learning 53 (1): 167-210. doi:10.1111/1467-9922.00227.

McKenzie, R. M. 2010. The Social Psychology of English as a Global Language. Attitudes, Awareness and Identity in the Japanese Context. Dordrecht: Springer.

Ministry of Education, Culture, and Sports. 2014. Enseñanzas no universitarias. Alumnado matriculado. http://www.educacion.gob.es/educabase/ (accessed November 8, 2014).

Moriarty, M. 2010. 'The Effects of Language Planning Initiatives on the Language Attitudes and Language Practices of University Students A Comparative Study of Irish and Basque.’ Language Problems \& Language Planning 34 (2): 141-157. doi:10.1075/lplp.34.2.03mor.

Navarro, J. L., and Á. Huguet. 2005. 'Avaluació de la competència en castellà de l’ alumnat immigrat de secundària a la província d’Osca.' Temps d'Educació 29: 217-228.

National Statistics Institute. 2014. Continuous Register Statistics. http://www.ine.es/jaxi/menu.do?type=pcaxis\&path=/t20/e245/\&file=inebase (accessed November 8, 2014).

Petty, R. E., and D. Wegener. 1998. 'Attitude change: Multiple Roles for Persuasion Variables.' In Handbook of Social Psychology, edited by Daniel T. Gilbert, Susan T. Fiske, and Gardner Lindzey, 323-90. 4th ed. New York: McGraw-Hill.

Petty, R. E., S. C. Wheeler, and Z. L. Tormala. 2003. 'Persuasion and Attitude Change.’ In Handbook of Psychology. Personality and Social Psychology, edited by T. Millon and M. J. Lerner, Vol. 5, 353-382. Hoboken, NJ: John Wiley \& Sons.

Rogosa, D. 1995. 'Myths and methods: ‘Myths about longitudinal research’ plus supplemental questions'. In The Analysis of Change, edited by John M. Gottman, 366. Mahwah, NJ: Lawrence Erlbaum.

Sharp, D., B. Thomas, E. Price, F. Gareth, and I. Davies. 1973. Attitudes to Welsh and English in the Schools of Wales. Basingstole: Macmillan. 
Schüpbach, D. 2009. 'Language Transmission Revisited: Family Type, Linguistic Environment and Language Attitudes.' International Journal of Bilingual Education and Bilingualism 12 (1): 15-30. doi:10.1080/13670050802149499.

Strubell, M. 2001. 'Catalan a Decade Later'. In Can Threatened Languages Be Saved, edited by Joshua Fishman, 260-283. Clevedon: Multilingual Matters.

Tabachnick, B.G., and L. S. Fidell. 2007. Using multivariate statistics. 5th ed. Boston: Pearson Education.

Tragant, E. 2006. 'Language Learning Motivation and Age.’ In Age and the Rate of Foreign Language Learning, edited by Carmen Muñoz, 237-236. Clevedon: Multilingual Matters.

Williams, R. H., and D. W. Zimmerman. 1996. 'Are Simple Gain Scores Obsolete?’ Applied Psychological Measurement 20 (1): 59-69. doi:10.1177/014662169602000106.

Wood, W. 2000. 'Attitude Change: Persuasion and Social Influence.' Annual Review of Psychology 51: 539-570. doi:10.1146/annurev.psych.51.1.539.

Zhang, D., and D. T. Slaughter-Defoe. 2009. 'Language Attitudes and Heritage Language Maintenance among Chinese Immigrant Families in the USA.' Language, Culture and Curriculum 22 (2): 77-93. doi:10.1080/07908310902935940.

\section{Appendix. English translation of the attitudes questionnaire}

Attitudes towards Catalan $(\alpha=.79)$

(1) I approve of all the children in my town studying Catalan.

(2) Learning Catalan is unpleasant.

(3) Learning Catalan is useless because I may never use it.

(4) We should all try harder to use Catalan more frequently.

(5) Learning English or French is more important than learning Catalan.

(6) I live in a place where Catalan is spoken, so I must know, study and speak Catalan.

(7) Only Catalan people should study Catalan.

(8) Catalan is an ill-sounding language.

(9) I like (or I would like) to speak Catalan. 
(10) I like listening to people speaking Catalan.

Attitudes towards Spanish $(\alpha=.75)$

(1) Spanish is a beautiful language.

(2) In my town, we must know how to speak Spanish.

(3) Spanish should only be learned and studied by Spanish speakers.

(4) I like listening to people speaking Spanish.

(5) In my town, other languages than Spanish should be studied.

(6) Catalan is more important than Spanish.

(7) Spanish is a language that is easy to learn.

(8) Learning Spanish is boring.

(9) Spanish should be taught in all countries.

(10) In my town, we should speak less Spanish.

Attitudes towards English $(\alpha=.77)$

(1) English is a beautiful language.

(2) All the persons living in Catalonia should know English.

(3) English should only be learned and studied in England or other countries where it is spoken.

(4) I like listening to people speaking English.

(5) In Catalonia, French should be studied more than English.

(6) I like (or I would like) to speak English.

(7) Learning English is useless because I may never use it.

(8) Learning English is boring.

(9) English should be taught in all the European countries.

(10) Catalan and Spanish are more important than English. 

Table 1. Descriptive statistics and summary of mixed-design ANOVA analyses for the effects of the categorical variables on attitude change towards Catalan, Spanish, and English

\begin{tabular}{|c|c|c|c|c|c|c|c|c|}
\hline \multirow[t]{2}{*}{ Variables } & & \multirow[t]{2}{*}{$N$} & \multicolumn{2}{|c|}{ Attitude change Catalan } & \multicolumn{2}{|c|}{$\begin{array}{l}\text { Attitude change } \\
\text { Spanish }\end{array}$} & \multicolumn{2}{|c|}{$\begin{array}{l}\text { Attitude change } \\
\text { English }\end{array}$} \\
\hline & & & $M$ & $S D$ & $M$ & $S D$ & $M$ & $S D$ \\
\hline \multirow[t]{2}{*}{ Gender } & Boys & 32 & 0.81 & 3.92 & -0.34 & 4.62 & -0.41 & 3.33 \\
\hline & Girls & 40 & 1.27 & 3.80 & 0.50 & 3.33 & 0.55 & 4.41 \\
\hline \multirow[t]{2}{*}{ Place of birth } & Catalonia & 12 & 2.42 & 5.07 & 0.67 & 3.92 & -1.33 & 3.58 \\
\hline & Foreign born & 60 & 0.80 & 3.53 & 0.02 & 3.98 & 0.42 & 4.01 \\
\hline \multirow{4}{*}{ Area of origin } & Europe & 18 & 0.05 & 3.76 & -0.61 & 4.07 & 0.50 & 5.33 \\
\hline & Africa & 20 & 2.45 & 4.21 & -0.70 & 5.00 & -1.15 & 4.20 \\
\hline & Latin America & 28 & 1.25 & 3.56 & 0.82 & 3.14 & 0.53 & 2.94 \\
\hline & Asia \& Oceania & 6 & -1.33 & 2.42 & 1.83 & 2.32 & 1.33 & 2.06 \\
\hline \multirow{3}{*}{$\begin{array}{l}\text { Socio- } \\
\text { professional } \\
\text { level }\end{array}$} & High & 12 & 0.50 & 1.73 & 1.58 & 3.17 & 1.92 & 2.84 \\
\hline & Medium & 16 & 2.19 & 3.87 & -0.25 & 3.78 & 0.56 & 4.84 \\
\hline & Low & 44 & 0.82 & 4.20 & -0.14 & 4.17 & -0.52 & 3.79 \\
\hline \multirow{3}{*}{$\begin{array}{l}\text { Socio- cultural } \\
\text { status }\end{array}$} & University & 28 & 0.21 & 2.90 & 1.00 & 2.62 & 0.75 & 3.09 \\
\hline & Secondary & 28 & 1.32 & 3.87 & -0.11 & 3.96 & -0.04 & 4.57 \\
\hline & Elementary & 16 & 2.12 & 4.98 & -1.00 & 5.50 & -0.69 & 4.30 \\
\hline
\end{tabular}

Note: $* p<.05$ 
Table 2. Descriptive statistics and summary of the simple linear regression analyses for the effects of the continuous variables on attitude change towards Catalan, Spanish, and English

\begin{tabular}{|c|c|c|c|c|c|c|c|c|c|c|c|c|c|c|}
\hline \multirow[t]{2}{*}{ Model } & \multicolumn{2}{|c|}{$\begin{array}{l}\text { Descriptive } \\
\text { statistics }\end{array}$} & \multicolumn{4}{|c|}{ Attitude change - Catalan } & \multicolumn{4}{|c|}{ Attitude change - Spanish } & \multicolumn{4}{|c|}{ Attitude change - English } \\
\hline & $M$ & $S D$ & $k$ & $b$ & $S E b$ & $\beta$ & $R^{2}$ & $b$ & $S E b$ & $\beta$ & $R^{2}$ & $b$ & $S E b$ & $\beta$ \\
\hline Length of residence & 6.21 & 4.60 & $.0 \overline{3}$ & 0.15 & 0.12 & .18 & .00 & -0.04 & 0.11 & -.05 & .03 & -0.15 & 0.09 & -.18 \\
\hline Use of Catalan & 1.94 & 0.82 & .05 & -1.08 & 0.52 & -.23 & .02 & -0.61 & 0.62 & -.13 & .03 & -0.80 & 0.56 & -.17 \\
\hline Use of Spanish & 2.31 & 0.78 & .01 & 0.47 & 0.52 & .10 & .05 & 1.16 & 0.76 & .23 & .01 & -0.16 & 0.70 & -.03 \\
\hline Use of L1 & 0.30 & 0.54 & .00 & 0.40 & 1.03 & .06 & .01 & -0.78 & 1.18 & -.11 & .00 & 0.40 & 0.97 & .05 \\
\hline $\begin{array}{l}\text { Self-identification } \\
\text { with Catalonia }\end{array}$ & 2.31 & 1.06 & .00 & -0.10 & 0.41 & -.03 & .03 & -0.67 & 0.42 & -.18 & .00 & -0.23 & 0.36 & -.06 \\
\hline $\begin{array}{l}\text { Self-identification } \\
\text { with Spain }\end{array}$ & 2.29 & 1.09 & .02 & -0.49 & 0.37 & -.14 & .01 & -0.14 & 0.37 & -.10 & .01 & -0.41 & 0.40 & -.11 \\
\hline $\begin{array}{l}\text { Self-identification } \\
\text { with area of origin }\end{array}$ & 3.47 & 0.75 & .00 & -0.22 & 0.51 & -.04 & .00 & -0.08 & 0.52 & .02 & .01 & 0.49 & 0.62 & .09 \\
\hline
\end{tabular}

Note: $* p<.05$ 
Figure 1. Means of attitudes towards Catalan, Spanish, and English by grade. Error bars represent plus and minus one standard error. 


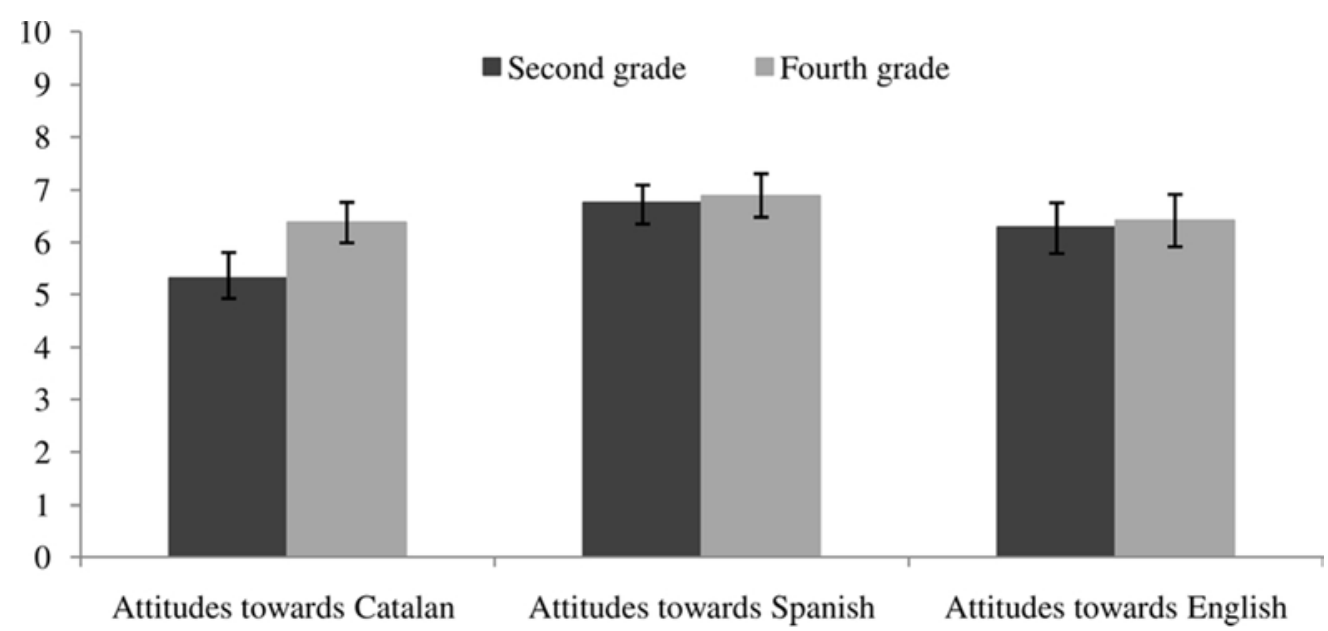

$79 \vee 2 ヶ 7 \mathrm{~m}(300 \times 300 \mathrm{DPI})$ 